\begin{tabular}{|c|c|c|}
\hline & $\begin{array}{l}\text { Jurnal Teknologi Kimia Unimal } \\
\text { http://ojs.unimal.ac.id/index.php/jtk }\end{array}$ & $\begin{array}{l}\text { Jurnal } \\
\text { Teknologi } \\
\text { Kimia } \\
\text { Unimal }\end{array}$ \\
\hline
\end{tabular}

\title{
PEMANFAATAN LIMBAH ALUMINIUM FOIL UNTUK PRODUKSI GAS HIDROGEN MENGGUNAKAN KATALIS NATRIUM HIDROKSIDA (NaOH)
}

\author{
Lukman Hakim ${ }^{1}$, Intan Marsalin ${ }^{1}$ \\ 1Jurusan Teknik Kimia, Fakultas Teknik, Universitas Malikussaleh \\ Laboratorium Teknik Kimia, Jl. Batam No. 2, Bukit Indah, Lhokseumawe 24535 \\ e-mail : intanmarsyalin@gmail.com
}

\begin{abstract}
Abstrak
Salah satu energi yang digunakan masyarakat adalah energi bahan bakar dari fosil. Sebagaimana kita ketahui, bahan bakar fosil termasuk salah satu jenis energi yang tidak dapat diperbaharui dan menghasilkan banyak emisi. Gas hidrogen termasuk jenis enegi yang dapat diperbaharui dan tidak menimbulkan emisi. Penelitian unsur hidrogen merupakan unsur terbanyak sehingga dapat menjadi solusi sebagai bahan bakar utama pengganti bahan bakar fosil. Tujuan penelitian ini adalah mengembangkan teknik daur ulang limbah aluminium foil untuk menghasilkan gas hidrogen sebagai energi yang ramah lingkungan dan dapat diperbaharui. Penelitian ini dilakukan dengan mereaksikan aluminium foil dan air dengan katalis $\mathrm{NaOH}$ pada suhu $35^{\circ} \mathrm{C}$. Di mana berat aluminium $1 \mathrm{gr}$, serta konsentrasi $\mathrm{NaOH}$ yang divariasikan $2 \mathrm{~N}, 3 \mathrm{~N}, 4 \mathrm{~N}, 5 \mathrm{~N}$ dan $6 \mathrm{~N}$, dan waktu reaksi 2 menit, 3 menit, 4 menit, dan 5 menit. Dari hasil penelitian menunjukkan bahwa volume hidrogen terbesar pada konsentrasi $\mathrm{NaOH} 6 \mathrm{~N}$ dan waktu reaksi 5 menit yaitu 1,938 liter. Untuk konversi aluminium tertinggi pada konsentrasi $\mathrm{NaOH} 6 \mathrm{~N}$ dan waktu reaksi 5 menit yaitu 51,346\%, sedangkan yield hidrogen tertinggi pada konsentrasi $\mathrm{NaOH} 6 \mathrm{~N}$ dan waktu reaksi 5 menit yaitu 6,229\%.
\end{abstract}

Kata kunci: $\quad$ aluminium foil, air, energi terbarukan, hidrogen, katalis

\section{Pendahuluan}

Krisis bahan bakar yang terjadi saat ini telah mengantarkan kita berfikir kreatif untuk menciptakan energi alternatif terbarukan yang dapat diperbaharui dan ramah lingkungan. Salah satu sumber energi alternatif yang ramah lingkungan adalah gas hidrogen. Pembakaran gas hidrogen dapat menghasilkan energi yang lebih tinggi yaitu sekitar $142 \mathrm{kj} / \mathrm{g}$ atau $3 \mathrm{kali}$ lebih baik jika dibandingkan hidrokarbon atau minyak bumi (Hafez et al., 2009). Gas hidrogen memiliki berbagai keuntungan dibanding bahan bakar yang lain, yaitu hidrogen adalah 
bahan bakar bersih (rendah polusi) yang memiliki kandungan energi tinggi dan tidak berkontribusi dalam polusi atau emisi gas rumah kaca ke atmosfer pada saat pembakaran. Selain itu, tidak menimbulkan penipisan lapisan ozon atau hujan asam karena pembakarannya hanya menyisakan uap air dan energi panas di udara (Kirtay, 2011).

Salah satu cara untuk menghasilkan hidrogen adalah dengan memanfaatkan aluminium, produksi hidrogen dengan menggunakan aluminium beralkalin untuk dijadikan fuel cell aluminium alkalin-udara yang ramah lingkungan. Aluminium yang digunakan dapat berasal dari limbah aluminium foil atau limbah minuman kaleng. Dalam jurnal Valensi Vol. 2 No. 1, Nop 2010 (362-367), telah dilakukan penelitian oleh Yusraini Dian Inayati Siregar tentang produksi gas hidrogen dari limbah aluminium menggunakan katalis basa dengan hasil produksi hidrogen optimum yang diperoleh adalah sebesar 0,006 gram dari 0,05 gram limbah aluminium (aluminium foil).

Selain memanfaatkan limbah aluminium foil (pembungkus makanan) untuk produksi hidrogen, proses ini juga ramah lingkungan. Untuk itulah perlu dilakukan penelitian produksi gas hidrogen dari limbah aluminium foil dengan menggunakan katalis $\mathrm{NaOH}$, untuk meningkatkan produksi gas hidrogen terutama untuk bahan bakar tidak berpolusi, sel bahan bakar (fuel cell), bahkan diperkirakan bahwa $\mathrm{H}_{2}$ ini akan dijadikan sumber energi terbarukan pada masa yang akan datang.

Isu lingkungan global yang menuntut tingkat kualitas lingkungan yang lebih baik, mendorong berbagai pakar energi untuk mengembangkan energi yang lebih ramah lingkungan dan mendukung keamanan pasokan berkesinambungan. Gas hidrogen $\left(\mathrm{H}_{2}\right)$ mempunyai gravimetrik densitas energi yang tertinggi diantara beberapa bahan bakar dan cocok untuk konversi energi tanpa menghasilkan emisi karbon yang telah memberikan konstribusi pada polusi lingkungan dan perubahan iklim. Gas hidrogen banyak digunakan untuk berbagai keperluan seperti bahan untuk sel bahan bakar, bahan pembuat amoniak, dan sebagainya. Hal ini lah yang menyebabkan permintaan konsumsi terhadap gas hidrogen meningkat. Menurut teoritis bahwa gas hidrogen juga dapat terbentuk dari aluminium. Sehingga 
dilakukan penelitian produksi gas hidrogen dari limbah aluminium foil dengan memperhatikan variabel operasinya.

Tujuan dari penelitian ini adalah untuk memanfaatkan limbah aluminium foil menjadi gas hidrogen dengan mereaksikan aluminium foil dengan basa, dan mempelajari variabel-variabel yang mempengaruhi produksi gas hidrogen dari aluminium foil bekas, diantaranya waktu reaksi, dan konsentrasi katalis.

Manfaat yang diperoleh dari penelitian ini adalah memahami produksi gas hidrogen dari aluminium foil yang dapat dijadikan sumber energi yang dapat diperbaharui, memberikan pengetahuan mengenai teknologi dalam menghasilkan energi terbarukan, dan sebagai bahan informasi kepada masyarakat akan pemanfaatan limbah aluminium foil untuk produksi gas hidrogen.

\section{Tinjauan Pustaka}

Kemasan fleksibel adalah suatu bentuk kemasan yang bersifat lentur yang dibentuk dari aluminium foil, film plastik, selopan, film plastik berlapis logam aluminium (metalized film) dan kertas dibuat satu lapis atau lebih dengan atau tanpa bahan thermoplastic maupun bahan perekat lainnya sebagai pengikat ataupun pelapis konstruksi kemasan dapat berbentuk lembaran, kantong, sachet maupun bentuk lainnya. Pemasaran kemasan ini akhir-akhir ini menjadi popular untuk mengemas berbagai produk baik padat maupun cair. Dipakai sebagai pengganti kemasan rigid maupun kemas kaleng atas pertimbangan ekonomis kemudahan dalam handling. Bentuk alumunium foil dapat dilihat pada Gambar 1 (Departemen perindustrian, 2007).

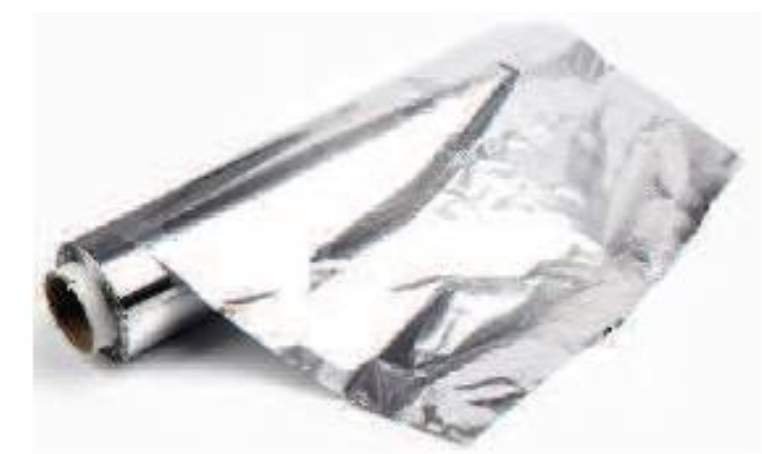

Gambar 1 Aluminium foil 
Limbah padat aluminium dibagi menjadi dua macam, yaitu limbah padat aluminium primer seperti kaleng minuman ringan (soft drink) dan minuman bir serta limbah padat aluminium sekunder seperti bingkai jendela dan pintu aluminium. Limbah padat aluminium sekunder berbeda dengan kualitasnya dengan limbah padat aluminium primer sehingga diperlukan perlakuan dan pemeriksaan limbah padat aluminium sekunder sebelum didaur ulang. Daur ulang aluminium adalah memproses kembali limbah aluminium (Suharto, 2011).

\section{Karakteristik aluminium}

Aluminium merupakan unsur yang sangat reaktif sehingga mudah teroksidasi. Karena sifat kereaktifannya maka Aluminium tidak ditemukan di alam dalam bentuk unsur melainkan dalam bentuk senyawa baik dalam bentuk oksida alumina maupun silikon. Sumber Aluminium yang sangat ekonomis adalah bauksit. Bauksit adalah biji yang banyak mengandung Alumina (Al2O3) yakni 30 - $60 \%$ serta 12 - $30 \%$ adalah air. Makin banyak oksida besi yang mengotori maka akan semakin gelap warnanya. Bauksit dapat berwarna putih, krem, kuning, merah atau coklat dapat sekeras batu. Namun ada pula yang selembek tanah lempung $\left(\mathrm{Al}_{2} \mathrm{O}_{3} \cdot 4 \mathrm{SiO}_{2} \cdot 2 \mathrm{H}_{2} \mathrm{O}\right)$. Paduan Aluminium mengandung $99 \%$ Aluminium dan $1 \%$ mengandung mangan, besi, silikon, tembaga, magnesium, seng, krom, dan titanium. Aluminium juga memiliki sifat yang lebih unggul dibandingkan dengan sifat logam lain. Sifat-sifat Aluminium yang lebih unggul bila dibandingkan dengan logam lain adalah sebagai berikut:

a. Ringan dengan massa jenis aluminium pada suhu kamar $\left(29^{\circ} \mathrm{C}\right)$ sekitar 2,7 $\mathrm{gr} / \mathrm{cm}^{3}$

b. Aluminium memiliki daya renggang $8 \mathrm{~kg} / \mathrm{mm}^{3}$, tetapi daya ini dapat berubah menjadi lebih kuat dua kali lipat apabila Aluminium tersebut dikenakan proses pencairan atau roling. Aluminium juga menjadi lebih kuat dengan ditambahkan unsur-unsur lain seperti Mg, Zn, Mn, Si.

c. Aluminium mengalami korosi dengan membentuk lapisan oksida yang tipis dimana sangat keras dan pada lapisan ini dapat mencegah karat pada aluminium yang berada di bawahnya. Dengan demikian logam aluminium adalah logam yang mempunyai daya tahan korosi yang lebih baik dibandingkan 
dengan besi dan baja lainnya.

d. Aluminium adalah logam yang paling ekonomis sebagai penghantar listrik karena massa jenisnya dari massa jenis tembaga, dimana kapasitas arus dari aluminium kira-kira dua kali lipat dari kapasitas arus pada tembaga.

e. Aluminium adalah logam yang anti magnetis.

f. Aluminium adalah logam yang tidak beracun dan tidak berbau.

g. Aluminium mempunyai sifat yang baik untuk proses mekanik dari kemampuan perpanjangannya, hal ini dapat dilihat dari proses penuangan, pemotongan, pembengkokan, ekstrusi dan penempaan aluminium.

h. Aluminium mempunyai titik lebur yang rendah, oleh karena itu kita dapat memperoleh kembali logam aluminium dari scrap.

\section{Metode Penelitian}

Penelitian dilaksanakan pada Mei-Juni 2016 dan tempat penelitian dilaksanakan di Laboratorium Teknik Kimia, Universitas Malikussaleh. Dalam pelaksanaan penelitian pembuatan gas hidrogen, beberapa variabel operasi yang digunakan yaitu berat aluminium foil, konsentrasi $\mathrm{NaOH}$, dan waktu reaksi.

Prosedurnya adalah limbah aluminium foil dibersihkan terlebih dahulu, kemudian dikecilkan ukurannya sampai $0,1 \mathrm{~cm}$ x $0,1 \mathrm{~cm}$ dan ditimbang dengan berat sampel 1 gram. $\mathrm{NaOH}$ disiapkan dan diencerkan masing-masing $25 \mathrm{ml}$ dengan konsentrasi yang berbeda-beda yaitu $2 \mathrm{~N}, 3 \mathrm{~N}, 4 \mathrm{~N}, 5 \mathrm{~N}$ dan $6 \mathrm{~N}$. Potongan aluminium foil dimasukkan ke dalam labu leher tiga. Masing-masing larutan $\mathrm{NaOH}$ direaksikan dengan potongan aluminium foil 1 gram. Direaksi pada waktu 2 menit dan diamati suhu konstan pada $35^{\circ} \mathrm{C}$. Untuk kandungan gas $\mathrm{H}_{2}$ yang dihasilkan dianalisis dengan metode penyulutan api. Proses diulangi untuk waktu reaksi 3 menit, 4 menit, dan 5 menit. Sampel yang telah direaksikan dengan $\mathrm{NaOH}$ di dalam labu leher tiga ditutup dengan balon agar $\mathrm{H}_{2}$ masuk ke dalam balon. Sehingga dapat dihitung volume $\mathrm{H}_{2}$ di dalam balon, konversi aluminium, yield hidrogen, dan pengujian gas hidrogen dengan cara pembakaran. 


\section{Hasil dan Diskusi}

Berdasarkan hasil penelitian yang diperoleh maka data hasil pengamatan didapat volume hidrogen yang diukur dengan metode balon dapat dilihat pada Tabel 1.

Tabel 1 Volume hidrogen dari limbah aluminium foil

\begin{tabular}{|c|c|c|c|c|}
\hline Run & $\begin{array}{c}\text { Berat } \\
\text { Aluminium } \\
\text { (gr) }\end{array}$ & $\begin{array}{l}\text { Waktu } \\
\text { (menit) }\end{array}$ & $\begin{array}{c}\text { Konsentrasi } \mathrm{NaOH} \\
\text { (N) }\end{array}$ & $\begin{array}{l}\text { Volume Hidrogen } \\
\text { (L) }\end{array}$ \\
\hline 1 & \multirow[t]{5}{*}{ 每 } & \multirow{5}{*}{2} & 2 & 0,580 \\
\hline 2 & & & 3 & 0,694 \\
\hline 3 & & & 4 & 0,927 \\
\hline 4 & & & 5 & 1,439 \\
\hline 5 & & & 6 & 1,489 \\
\hline 6 & \multirow{5}{*}{1} & \multirow{5}{*}{3} & 2 & 1,372 \\
\hline 7 & & & 3 & 1.499 \\
\hline 8 & & & 4 & 1,592 \\
\hline 9 & & & 5 & 1,655 \\
\hline 10 & & & 6 & 1,754 \\
\hline 11 & \multirow{5}{*}{1} & \multirow{5}{*}{4} & 2 & 1,571 \\
\hline 12 & & & 3 & 1,743 \\
\hline 13 & & & 4 & 1,754 \\
\hline 14 & & & 5 & 1,845 \\
\hline 15 & & & 6 & 1,937 \\
\hline 16 & \multirow{5}{*}{1} & \multirow{5}{*}{5} & 2 & 1,777 \\
\hline 17 & & & 3 & 1,892 \\
\hline 18 & & & 4 & 1,904 \\
\hline 19 & & & 5 & 1,928 \\
\hline 20 & & & 6 & 1,938 \\
\hline
\end{tabular}

Tabel 1 menunjukkan volume hidrogen yang tertinggi adalah pada waktu 5 menit dan konsentrasi $\mathrm{NaOH} 6 \mathrm{~N}$ yaitu 1,938 liter. Untuk volume hidrogen yang terendah pada waktu 2 menit dan konsentrasi $\mathrm{NaOH} 2 \mathrm{~N}$ yaitu 0,580 liter. Hasil penelitian gas hidrogen dari limbah aluminium foil untuk konversi aluminium dan yield hidrogen dapat dilihat pada Tabel 2 dengan variasi $\mathrm{NaOH}(2 \mathrm{~N}, 3 \mathrm{~N}, 4 \mathrm{~N}, 5 \mathrm{~N}$ dan $6 \mathrm{~N}$ ) dan waktu reaksi (2 menit, 3 menit, 4 menit, dan 5 menit).

Tabel 2 menunjukkan bahwa konversi aluminium tertinggi pada waktu 5 menit dan konsentrasi $\mathrm{NaOH} 6 \mathrm{~N}$ yaitu 51,346\%, sedangkan konversi aluminium terendah pada waktu 2 menit dan konsentrasi $\mathrm{NaOH} 2 \mathrm{~N}$ yaitu 34,090\%. Untuk yield hidrogen tertinggi pada waktu 5 menit dan konsentrasi $\mathrm{NaOH} 6 \mathrm{~N}$ yaitu Makalah sudah dipresentasikan dalam Seminar Nasional Teknik Kimia 73 UNIMAL 2016 (17 Oktober 2016) 
$6,229 \%$, serta yield hidrogen terendah pada waktu 2 menit dan konsentrasi $\mathrm{NaOH}$ $2 \mathrm{~N}$ yaitu $1,719 \%$.

Tabel 2 Hasil penelitian gas hidrogen dari limbah aluminium

\begin{tabular}{|c|c|c|c|c|}
\hline \multirow[b]{2}{*}{ Run } & \multicolumn{2}{|c|}{ Variabel bebas } & \multicolumn{2}{|c|}{ Variabel terikat } \\
\hline & $\begin{array}{c}\text { Konsentrasi } \\
\mathrm{NaOH}(\mathrm{N})\end{array}$ & $\begin{array}{l}\text { Waktu } \\
\text { (menit) }\end{array}$ & $\begin{array}{c}\text { Konversi } \\
\text { Alminium (\%) }\end{array}$ & $\begin{array}{c}\text { Yield Hidrogen } \\
(\%)\end{array}$ \\
\hline 1 & 2 & \multirow{5}{*}{2} & 34,090 & 1,719 \\
\hline 2 & 3 & & 36,121 & 2,097 \\
\hline 3 & 4 & & 37,459 & 2,859 \\
\hline 4 & 5 & & 39,546 & 4,529 \\
\hline 5 & 6 & & 40,750 & 4,786 \\
\hline 6 & 2 & \multirow{5}{*}{3} & 35,693 & 4,065 \\
\hline 7 & 3 & & 38,074 & 4,531 \\
\hline 8 & 4 & & 39,442 & 4,909 \\
\hline 9 & 5 & & 40,937 & 5,209 \\
\hline 10 & 6 & & 42,632 & 5,640 \\
\hline 11 & 2 & \multirow{5}{*}{4} & 40,643 & 4,656 \\
\hline 12 & 3 & & 41,740 & 5,270 \\
\hline 13 & 4 & & 42,216 & 5,411 \\
\hline 14 & 5 & & 42,917 & 5,807 \\
\hline 15 & 6 & & 51,239 & 6,228 \\
\hline 16 & 2 & \multirow{5}{*}{5} & 42,543 & 5,267 \\
\hline 17 & 3 & & 44,202 & 5,720 \\
\hline 18 & 4 & & 44,496 & 5,873 \\
\hline 19 & 5 & & 50,168 & 6,066 \\
\hline 20 & 6 & & 51,346 & 6,229 \\
\hline
\end{tabular}

Penelitian ini dilakukan dengan mereaksikan limbah aluminium foil dengan katalis basa untuk menghasilkan gas hidrogen, katalis yang digunakan adalah Natrium Hidroksida $(\mathrm{NaOH})$. Natrium hidroksida $(\mathrm{NaOH})$ adalah bahan kimia berbentuk kristal putih padat yang apabila memasuki lingkungan akan mudah bereaksi memecah dengan bahan kimia lain. Penggunaan natrium hidroksida $(\mathrm{NaOH})$ adalah sebagai katalisator yang berperan mempercepat reaksi dengan aluminium. Katalis dapat menurunkan energi aktivasi sehingga mampu meningkatkan laju reaksi agar reaksi kimia dapat mencapai kesetimbangan, tanpa 
terlibat didalam reaksi secara permanen. Energi aktivasi adalah energi minimum yang dibutuhkan sehingga partikel dapat bertumbukan dan menghasilkan reaksi.

Reaksi antara aluminium dan air dengan Natrium Hidroksida $(\mathrm{NaOH})$ untuk produksi hidrogen dapat ditunjukkan pada reaksi dibawah ini:

$$
\begin{aligned}
& 2 \mathrm{Al}+6 \mathrm{H}_{2} \mathrm{O}+2 \mathrm{NaOH} \rightarrow 2 \mathrm{NaAl}(\mathrm{OH})_{4}+3 \mathrm{H}_{2} \\
& \mathrm{NaAl}(\mathrm{OH}) 4 \rightarrow \mathrm{NaOH}+\mathrm{Al}(\mathrm{OH})_{3}
\end{aligned}
$$

Natrium hidroksida $(\mathrm{NaOH})$ dikonsumsi untuk produksi hidrogen dengan reaksi eksoterm (4.1) dan akan diproduksi ulang melalui reaksi dekomposisi $\mathrm{NaAl}(\mathrm{OH})_{4}$. Reaksi (4.2) akan menghasilkan endapan kristal aluminium hidroksida $\left(\mathrm{Al}(\mathrm{OH})_{3}\right)$. Kombinasi dari dua reaksi diatas menunjukkan bahwa hanya air yang dikonsumsi untuk produksi hidrogen jika dilihat dari reaksi tersebut (Kumar dan Surendra, 2013).

Penggunaan natrium hidroksida $(\mathrm{NaOH})$ adalah sebagai katalisator yang berperan mempercepat reaksi dengan aluminium. Katalis dapat menurunkan energi aktivasi sehingga mampu meningkatkan laju reaksi agar reaksi kimia dapat mencapai kesetimbangan, tanpa terlibat didalam reaksi secara permanen. Energi aktivasi adalah energi minimum yang dibutuhkan sehingga partikel dapat bertumbukkan dan menghasilkan reaksi.

Dari reaksi (4.1) aluminium bereaksi dengan natrium hidroksida dan air membentuk natrium aluminat $\left(\mathrm{NaAl}(\mathrm{OH})_{4}\right)$ atau senyawa komplek $\left(\mathrm{NaAl}(\mathrm{OH})_{4}\right)$ kemudian bereaksi kembali pada reaksi dekomposisi (4.2) menghasilkan aluminium hidroksida $\left(\mathrm{Al}(\mathrm{OH})_{3}\right)$.

Pada saat potongan kecil limbah aluminium foil di masukkan kedalam labu leher tiga yang berisi larutan natrium hidroksida terjadi gelembung-gelembung pada potongan aluminium foil tersebut, selanjutnya gas yang dihasilkan ditampung menggunakan balon. Untuk mengidentifikasi dan memastikan telah dihasilkan hidrogen dalam reaksi yaitu dengan melakukan pengujian pembakaran gas hidrogen seperti terlihat pada Lampiran C. Gas hidrogen sangat mudah terbakar dan akan terbakar pada konsentrasi serendah $4 \%$ di udara bebas. Karakteristik lainnya dari api hidrogen adalah nyala api cenderung menghilang 
dengan cepat di udara, sehingga kerusakan akibat ledakan hidrogen lebih ringan dari ledakan hidrokarbon (College Of Desert,2001).

\subsection{Pengaruh Konsentrasi Natrium Hidroksida ( $\mathrm{NaOH})$ dan Waktu Reaksi Terhadap Volume Gas Hidrogen}

Konsentrasi sangat berpengaruh terhadap reaksi antara limbah aluminium foil dengan larutan natrium hidroksida $(\mathrm{NaOH})$, analisa kimia kuantitatif digunakan untuk mendapatkan data mengenai produksi gas hidrogen dari limbah aluminium foil dengan larutan natrium hidroksida $(\mathrm{NaOH})$ tersebut dengan konsentrasi $(2 \mathrm{~N}, 3 \mathrm{~N}, 4 \mathrm{~N}, 5 \mathrm{~N}$, dan $6 \mathrm{~N})$, jumlah aluminium 1 gr, dan waktu (2 menit, 3 menit, 4 menit, dan 5 menit). Pengukuran dilakukan untuk mengetahui pengaruh konsentrasi natrium hidroksida terhadap volume gas hidrogen yang dihasilkan. Konsentrasi atau kepekatan adalah perbandingan jumlah zat terlarut terhadap jumlah larutan. Pengaruh konsentrasi terhadap laju reaksi adalah semakin besar konsentrasi pereaksi atau semakin pekat pereaksinya maka semakin cepat reaksi berlangsung. Dalam larutan yang konsentrasinya tinggi atau larutan pekat maka makin banyak jumlah molekulnya. Banyaknya jumlah molekul menyebabkan letak molekul yang lebih rapat dan berdekatan sehingga molekulmolekulnya lebih mudah dan sering untuk bertumbukan. Itulah sebabnya, makin besar konsentrasi suatu larutan, makin besar pula laju reaksinya.

Berikut ini pengaruh konsentrasi terhadap volume gas hidrogen dengan variasi konsentrasi $(2 \mathrm{~N}, 3 \mathrm{~N}, 4 \mathrm{~N}, 5 \mathrm{~N}$, dan $6 \mathrm{~N})$ yang ditunjukkan pada Gambar 1. Pada penelitian ini jumlah aluminium foil ditetapkan sebanyak 1 gram sedangkan konsentrasi $\mathrm{NaOH}$ divariasikan. Berdasarkan gambar 1 dapat dilihat bahwa volume hidrogen semakin bertambah dengan kenaikan konsentrasi $\mathrm{NaOH}$, pada konsentrasi tertinggi yaitu $6 \mathrm{~N}$ volume hidrogen yang dihasilkan lebih besar dari konsentrasi $2 \mathrm{~N}, 3 \mathrm{~N}, 4 \mathrm{~N}$, dan $5 \mathrm{~N}$. Hal ini dapat disimpulkan bahwa dalam penelitian ini semakin tinggi konsentrasi natrium hidroksida $(\mathrm{NaOH})$ volume hidrogen makin bertambah. Ini dikarenakan larutan $\mathrm{NaOH}$ berfungsi membantu aluminium mengikat $\mathrm{OH}$ - dari air membentuk $\mathrm{NaAl}(\mathrm{OH})_{4}$, sehingga melepaskan hidrogen, seperti yang ditunjukkan pada reaksi (4.1) dan (4.2) (Kumar dan 
Surenda, 2013). Dalam penelitian ini volume hidrogen terbesar pada konsentrasi 6N yaitu 1,938 liter. Berdasarkan penelitian Porciuncula dkk (2012) mengatakan produksi hidrogen dipengaruhi oleh suhu, konsentrasi alkali, dan bentuk logam. Siregar (2012) mengatakan bahwa semakin tinggi jumlah aluminium, maka gas hidrogen yang dihasilkan semakin besar, sedangkan laju reaksi tertinggi pada konsentrasi $\mathrm{NaOH}$ tertinggi.

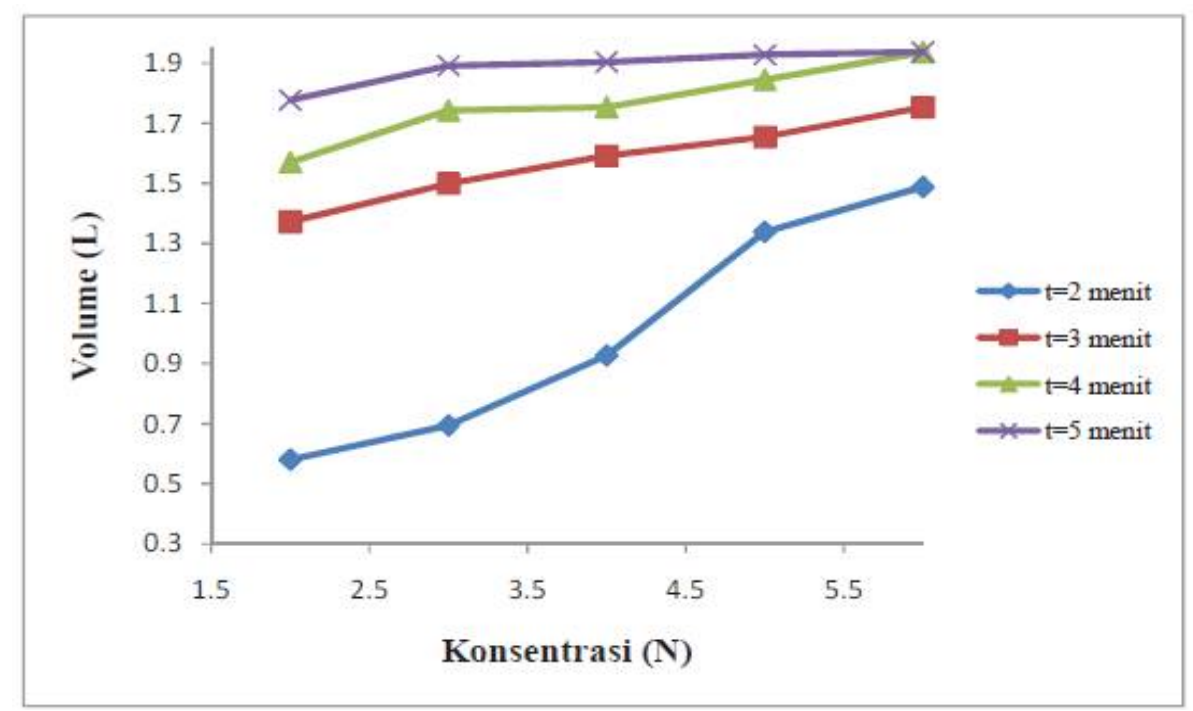

Gambar 1 Pengaruh konsentrasi $\mathrm{NaOH}$ terhadap volume gas hidrogen

Pada penelitian juga dilakukan variasi waktu reaksi yaitu 2 menit, 3 menit, 4 menit, dan 5 menit, volume gas hidrogen akan bertambah dengan semakin lamanya waktu reaksi. Dalam reaksi ini terbentuk gas $\mathrm{H}_{2}$ yang ditandai dengan munculnya gelembung-gelembung gas. Setelah semua aluminium bereaksi gelembung-gelembung gas akan menghilang dan larutannya berubah menjadi warna abu-abu, besar konsentrasi dari katalis yang dalam hal ini adalah $\mathrm{NaOH}$ maka waktu yang diperlukan untuk alumunium foil habis bereaksi adalah semakin cepat. Sehingga untuk mendapatkan hasil maksimal gas hidrogen dengan memperbanyak alumunium foil dan memperbesar konsentrasi katalisnya.

Dalam penelitian ini volume hidrogen terbesar pada waktu 5 menit dan konsentrasi 6N yaitu 1,938 liter. Hal ini membuktikan bahwa semakin lama waktu reaksi, maka volume gas hidrogen yang dihasilkan akan semakin banyak. Apabila natrium hidroksida $(\mathrm{NaOH})$ dimasukkan dalam air akan memisahkan kation 
natrium (sodium atom bermuatan positif) dan anion hidroksida (oksigen dan hidrogen atom bermuatan negatif). Ion $\mathrm{OH}-$ pada larutan alkali tersebut dapat merusak lapisan oksida pelindung pada permukaan aluminium serta menjadi promotor pada reaksi aluminium dengan air. Karena kecenderungan aluminium mudah dioksidasi, reaksi aluminium dengan larutan alkali tersebut menghasilkan senyawa komplek $\mathrm{NaAl}(\mathrm{OH})_{4}$ dan Hidrogen.

\subsection{Pengaruh Konsentrasi Natrium Hidroksida (NaOH) dan Waktu Reaksi Terhadap Konversi aluminium}

Ketika reaksi antara aluminium dan air dibantu oleh $\mathrm{NaOH}$, ion $\mathrm{OH}^{-}$pada larutan alkali akan menjadi promotor dalam reaksi tersebut yang dapat merusak lapisan oksida pelindung pada permukaan aluminium sehingga melepaskan hidrogen, dan $\mathrm{NaOH}$ bertindak sebagai katalis yang akan meningkatkan laju reaksi agar reaksi tersebut mencapai kesetimbangan (Kumar dan surendra, 2013). Pengaruh konsentrasi natrium hidroksida $(\mathrm{NaOH})$ dan jumlah aluminium terhadap konversi aluminium dapat dilihat pada Gambar 2.

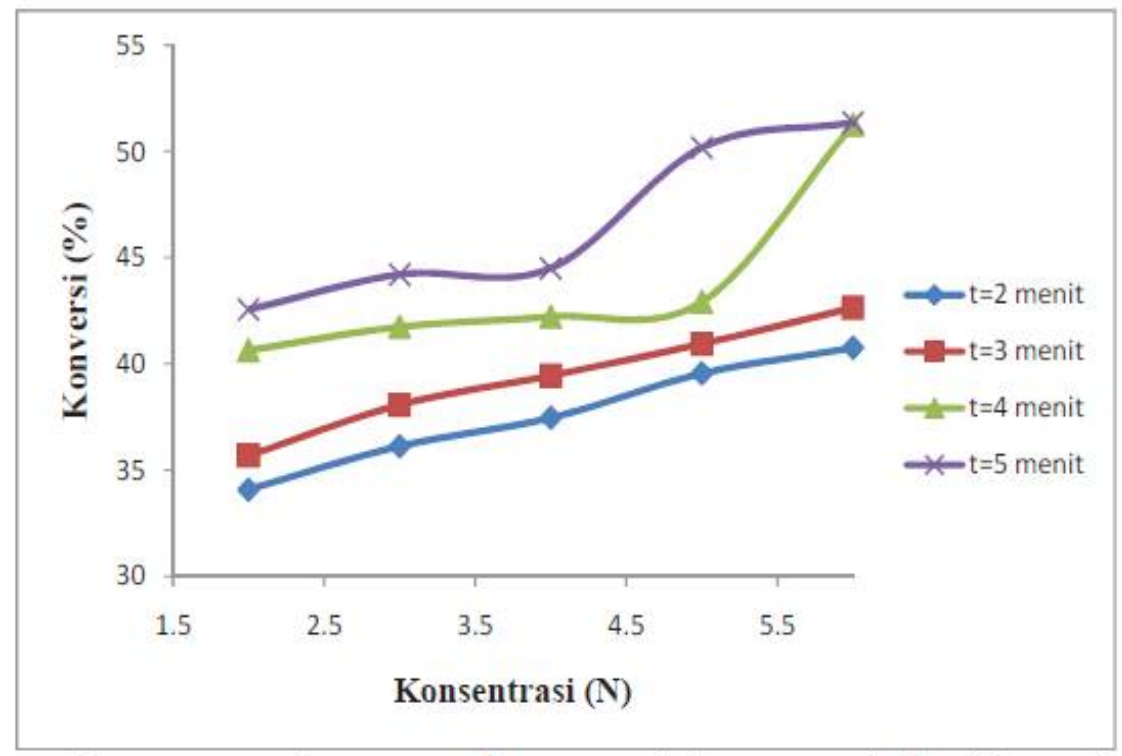

Gambar 2 Pengaruh konsentrasi $\mathrm{NaOH}$ terhadap konversi aluminium foil

Berdasarkan Gambar 2, pengaruh konsentrasi $\mathrm{NaOH}$ terhadap konversi aluminium, semakin tinggi konsentrasi $\mathrm{NaOH}(2 \mathrm{~N}, 3 \mathrm{~N}, 4 \mathrm{~N}, 5 \mathrm{~N}$, dan $6 \mathrm{~N})$ maka konversi aluminium semakin tinggi. Konversi aluminium tertinggi pada 
konsentrasi $\mathrm{NaOH} 6 \mathrm{~N}$ dibandingkan dari konsentrasi $\mathrm{NaOH} 5 \mathrm{~N}, 4 \mathrm{~N}, 3 \mathrm{~N}$, dan $2 \mathrm{~N}$. Hal ini dikarenakan pada konsentrasi $\mathrm{NaOH}$ yang lebih tinggi menunjukkan jumlah $\mathrm{NaOH}$ lebih banyak. $\mathrm{NaOH}$ adalah sebagai katalis reaktif yang dapat merusak lapisan oksida $\left(\mathrm{Al}_{2} \mathrm{O}_{3}\right)$ pelindung pada permukaan aluminium serta membantu aluminium mengikat $\mathrm{OH}$ - dari air membentuk $\mathrm{NaAl}(\mathrm{OH})_{4}$ sehingga melepaskan hidrogen. Dari penelitian diperoleh konversi tertinggi yaitu 51,346\% pada konsentrasi $6 \mathrm{~N}$.

Sedangkan untuk waktu reaksi diperoleh konversi tertinggi pada waktu 5 menit dan konsentrasi $6 \mathrm{~N}$ yaitu 51,346\%, hal ini dikarenakan semakin lama waktu reaksi, maka aluminium foil yang terkonversi akan semakin banyak. Dan konversi terendah pada konsentrasi $2 \mathrm{~N}$ dan waktu 2 menit yaitu 34,090\%. Dari hasil tersebut dapat disimpulkan bahwa dengan bertambahnya konsentrasi $\mathrm{NaOH}$ dan waktu reaksi sangat mempengaruhi konversi aluminium.

\subsection{Pengaruh Konsentrasi Natrium Hidroksida (NaOH) dan Waktu Reaksi Terhadap Yield Hidrogen}

Berdasarkan penelitian yang telah dilakukan, pengaruh konsentrasi natrium hidroksida $(\mathrm{NaOH})$ dan jumlah aluminium terhadap yield hidrogen dapat dilihat pada Gambar 3.

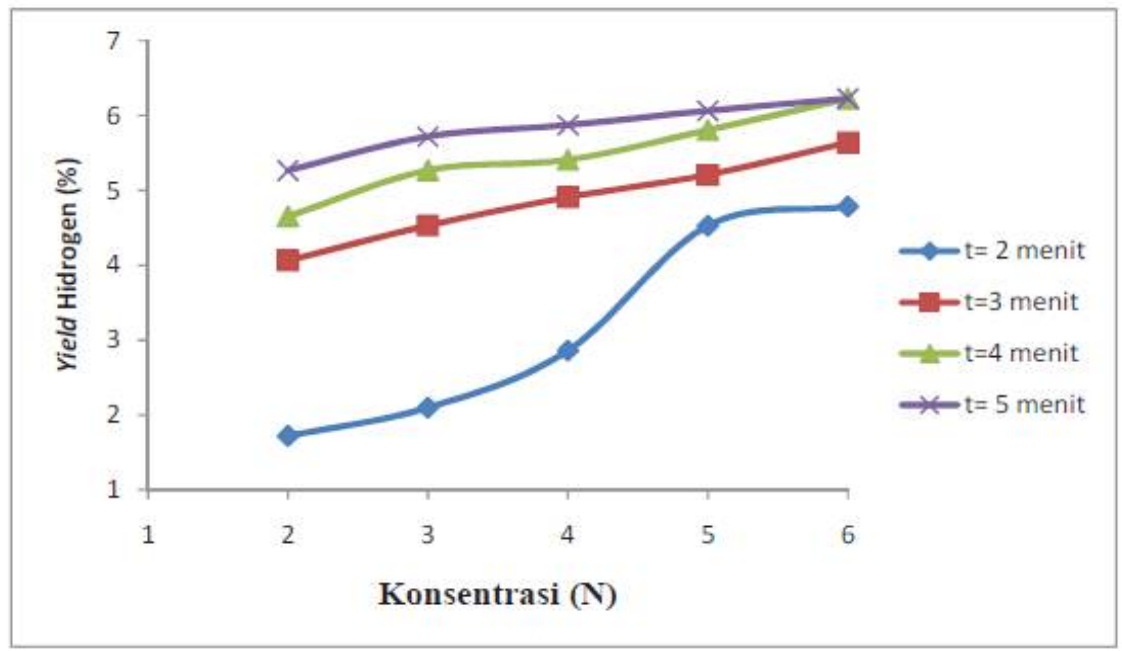

Gambar 3 Pengaruh konsentrasi $\mathrm{NaOH}$ terhadap yield hidrogen 
Berdasarkan penelitian yang dilakukan dengan berat aluminium foil 1 gram dapat dilihat pada Gambar 4.3 bahwa semakin tinggi konsentrasi $\mathrm{NaOH}(2 \mathrm{~N}, 3 \mathrm{~N}$, $4 \mathrm{~N}, 5 \mathrm{~N}$, dan $6 \mathrm{~N}$ ) maka yield hidrogen yang dihasilkan semakin tinggi, dan sebaliknya semakin rendah konsentrasi $\mathrm{NaOH}$ maka yield hidrogen yang dihasilkan semakin rendah. Yield tertinggi pada konsentrasi 6N yaitu 6,229\%, begitu juga dengan variasi waktu reaksi, pada waktu terlama diperoleh yield hidrogen tertinggi yaitu pada waktu 5 menit. Hal ini dapat disimpulkan dengan bertambahnya konsentrasi dan waktu reaksi maka yield hidrogen akan semakin bertambah. Pengaruh konsentrasi dapat diamati dalam persamaan laju reaksi, dimana jika konsentrasi pereaksinya masing-masing dinaikkan maka laju reaksinya pun semakin cepat dari laju awal.

Hal tersebut analog dengan peristiwa tumbukan antara larutan dengan konsentrasi yang tinggi dengan larutan konsentrasi rendah. Pada konsentrasi tinggi jumlah partikel terlarut yang banyak menyebabkan jarak antar partikel menjadi lebih rapat dan kemungkinan untuk terjadinya tumbukan lebih besar dibandingkan dengan larutan konsentrasi rendah. Sehingga yield yang dihasilkan semakin besar karena dalam larutan yang konsentrasinya tinggi atau larutan pekat maka makin banyak jumlah molekulnya. Banyaknya jumlah molekul menyebabkan letak molekul yang lebih rapat dan berdekatan sehingga molekulmolekulnya lebih mudah dan sering untuk bertumbukan. Itulah sebabnya, makin besar konsentrasi suatu larutan, makin besar pula laju reaksinya. Besarnya laju reaksi dapat meningkatkan yield hidrogen yang diperoleh.

\section{Simpulan}

Berdasarkan hasil penelitian dan pengolahan data maka dapat diambil kesimpulan yaitu sebagai berikut:

1. Natrium hidroksida $(\mathrm{NaOH})$ berfungsi sebagai katalis dalam reaksi aluminium dengan air, serta membantu aluminium mengikat $\mathrm{OH}^{-}$dari senyawa air membentuk $\mathrm{NaAl}(\mathrm{OH})_{4}$ sehingga melepaskan hidrogen.

2. Volume hidrogen tertinggi diperoleh pada waktu reaksi 5 menit dan konsentrasi $\mathrm{NaOH} 6 \mathrm{~N}$ yaitu 1,938 liter. 
3. Konversi aluminium tertinggi terdapat pada berat aluminium 1 gr dengan konsentrasi natrium hidroksida $(\mathrm{NaOH}) 6 \mathrm{~N}$ dan waktu reaksi 5 menit yaitu $51,346 \%$.

4. Yield hidrogen yang tertinggi terdapat pada berat aluminium foil $1 \mathrm{gr}$ dengan konsentrasi natrium hidroksida $(\mathrm{NaOH}) 6 \mathrm{~N}$ dan waktu reaksi 5 menit yaitu $6,229 \%$.

\section{Daftar Pustaka}

Agus, W. dan Jajang, J. 2014. Pemanfaatan Hidrogen Hasil Reaksi Water Replacement Berbahan Baku Kaleng Bekas Untuk Bahan Bakar Mesin Diesel Sistim Dual Fuel. Pekanbaru: Politeknik Caltex Riau.

College Of The Desert. 2001. Modul 1 Hydrogen Properties. Hydrogen Fuel Cell Engines and Related Technologies. http://www1.eere.energy.gov/hydrogenand fuel cells/tech_validation/pdfs/fcm01r0.pdf (diakses pada 19 Februari 2016 pukul 22.30 WIB).

Douglas M. C. P. E. 1983. Scientific Encyclopedia. Australia: Van Mostran Reinold Company.

Siregar, Y. D. I. 2010. Produksi Gas Hidrogen dari Limbah Aluminium. Jurnal Valensi. Volume 2, No. 1, 362-36.

Siregar, Y. D. I. 2012. Produksi Gas Hidrogen dari Limbah Aluminium dan Uji Daya Listrik dengan Fuel Cell. Portal Garuda. Volume 2, No 5:573-580.

Suharto. 2011. Limbah Kimia dalam Pencemaran Udara dan Air. Yogyakarta: Andi Offset. Hal. 313-317, 321.

Takehito, H., Masato, T., Masaki, H., dan Tomohiro, A. 2005. Hydrogen Production from Waste Aluminum at Different Temperatures with LCA. Journal of Materials Transactions, Vol. 46, No. 5 pp 1052-1057. 